\title{
ACADEMIC LIFE
}

НАУЧНАЯ ЖИЗНЬ

\section{Book review: Leenco Lata Peacekeeping as State-Building: Current Challenges for the Horn of Africa. Ewing Township, USA: The Red Sea Press. 2012. 160 p.}

\author{
B.D. Gardachew
}

\author{
Bahir Dar University \\ Bahir Dar, Ethiopia
}

\begin{abstract}
The review of Leenco Lata's ${ }^{1}$ book "Peacekeeping as State-Building: Current Challenges for the Horn of Africa" examines the theory and practice of state-building on the example of African countries. The central premise of this monograph is the assumption that state-building requires rethinking of the factors and attributes traditionally associated with the state. The book consists of nine chapters, each of which is analyzed by the reviewer. The monograph focuses on the problems of state-building, state legitimacy, and the role and specifics of peacekeeping operations in the horn of Africa.
\end{abstract}

Keywords: peacekeeping, state-building, Horn of Africa, democracy, political stability

The overall goal of this work is to make a modest contribution to the emerging field of state-building theory. Hence, the central message of this work is a supposition that state-building requires rethinking the attributes conventionally associated with the state. The book is organized into nine chapters. The first chapter is an introductory section, which narrates mainly about state formation, state legitimacy and peacekeeping operations in the Horn of Africa.

(C) Gardachew B.D., 2019.

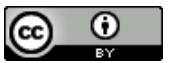

This work is licensed under a Creative Commons Attribution 4.0 International License https://creativecommons.org/licenses/by/4.0/

${ }^{1}$ The author studied engineering in the US in the 1960s and, upon returning to Ethiopia, joined other Oromos to establish the Oromo Liberation Front (OLF). As a member of the OLF leadership, Lata collaborated with the present leaders of Ethiopia and Eritrea to chart the course that led to Eritrea's separation and the reconfiguration of the remainder of Ethiopia as a federation. The author currently lives in Oslo and is associated with the Norwegian Research Institution. Lata works as a freelance analyst of political developments in the Horn of Africa. He is the author of the "Ethiopian State at the Crossroads" (1999) and the "Horn of Africa as Common Homeland" (2004), as well as numerous other articles. 
In this chapter, the book argues that state formation was the result of the late $19^{\text {th }}$ century settlements: European imperialists (Britain, France and Italy) that came mainly from outside the region, and internal imperialists (Christian Abyssinia and Mahdist Sudan), which appeared from within the region. 'State legitimacy' is conceptualized as a degree to which the idea of state formation is shared by all the people residing on the territory of the state. However, as is demonstrated in the book, in the Horn of Africa, the shared idea of a state has not been particularly unanimous. Hence, the 'state' is legitimate for some residents and unenforceable for others. Another aspect in the purview of the chapter is expansion of peacekeeping doctrine in the Horn of Africa. Currently a number of peacekeeping operations are being conducted in the region. It is argued, however, that the peacemaking forces lack a consensual approach in the matters of state formation. The book underscores that the goal of peacekeeping is building a preeminently democratic state and not just any kind of state.

The second chapter of the book is devoted to state building and the challenges associated with it, such as asymmetrical flow of resources, nation-building, external recognition and legitimacy. With regard to asymmetrical flow of resources, it is argued that debt servicing and the ever rising gap between the prices of raw materials exported by poor countries and the prices of industrial products they import from wealthy favors the latter. The book claims that African countries would never be able to sustain institutions and practices underpinning a modern democratic state unless the ongoing asymmetrical flow of resources is corrected. At the same time, the current attempt at nation-building in the region may result in the prevalence on some nations over others in the number of residents populating the state. The author believes that such practice will lead to reactive nationalism, which consequently may result in the state's failure. Therefore, nation-building may become the reason for the fiasco of the state. Furthermore, the author strongly believes that external recognition determines the acknowledgment of internal legitimacy. The author insists that any regime that lacks internal legitimacy cannot guarantee the legality of its external regulations.

The third chapter of the book deals with determining the size of the state in the Horn of Africa, where the concurrent existence of expansionist and contractionist tendencies within a state should be taken into consideration. It is argued that some of the region's states aspire to achieve expansion by claiming the whole or parts of a neighboring entity. If nothing else, there exists projection of power and influence into neighboring states. At the same time, there is at least one group entertaining separation or, at the minimum, decentralization. According to the author, any state-building initiative that overlooks the co-occurrence of expansionist and contractionist tendencies is very unlikely to succeed. Lata suggests that regional integration combined with decentralization should be a response to the local nature of many African problems.

Chapter four discusses the role of traditions in the state formation. The author notes that African political traditions and attitudes were heavily influenced by the Enlightenment movement that spread from Europe. Educated Africans, who 
were under the influence of European theories about Africa and African societies, relinquished African traditions, dismissing the positive elements of their conventional practices and structures. The author underlines that in the process of statebuilding, a society's traditions should be reckoned with and looked upon as fundamental principles, "the bedrock" for the future nation. According to Lata, building a sustainable and robust state in Africa would be unthinkable unless traditional structures, practices and formations are taken into account.

Chapter five of the book is devoted to state ownership. In this chapter, the author indicates that state ownership and state legitimacy are contested to various degrees practically in every state in the Horn of Africa. He mentions that policies, practices, symbols and myths of each state grant privileges to a particular part of population and ignore the interests of others. The author stresses that many of the conflicts in the Horn of Africa stem from the asymmetrical nature of state ownership.

In chapter six, the author states that in order to successfully build a democratic state in the Horn of Africa, it is imperative to use a version of democracy that takes into account cultural and linguistic diversity. Lata argues that liberal democracy is not preferable for Africa, as it lacks sensitivity to cultural pluralism and leans upon a strong economy. The author opts for the deliberative version of democracy as opposed to the liberal one. He emphasizes that deliberative democracy reconciles the interests of the common national and a particular ethnic identity.

In chapter seven, the issues of diversity and citizenship are discussed. The world in general and the Horn of Africa in particular are culturally and ethnically diverse; therefore, recognizing these identities is the only way to build a civilized society. The author suggests that in the process of state and citizenship formation the existence of such diversity needs to be acknowledged.

Chapter eight of the book focuses on legitimacy of military and security institutions. The author points out that state-building cannot be successful unless these sectors are legitimized. He recommends that military and security forces should serve as protectors of all spheres of the state with authorization to do so being derived from all members of society. The book further argues that, in the Horn of Africa, where the military has transformed itself into a political party, the fundamental challenge is to end militarization of political parties and politicization of military forces.

Finally, in the last chapter, the author summarizes four imperatives that need to be addressed for sustainable peace and stability to prevail in the strife-torn region of the Horn of Africa. The imperatives include: addressing the concurrent expansionist and contractionist tendencies; ensuring the symmetry of state ownership; providing accountability and accessibility of state institutions to grassland communities; recognizing ethnic diversity and various identities.

The main strength of this book is that it gives a comprehensive description of the state-building process and the challenges associated with it in regards to each state in the Horn of Africa. The way the author comes up with alternatives to the problems raised in the discussion presents a particular interest. The reviewer believes that the ideas suggested by the author are applicable in various ways. 
Lata offers a different perspective regarding the relations between state and society, which he sets in opposition to the existing common practice of state autonomy prevailing over societal autonomy. The existing tradition views state is a sovereign entity standing above and controlling society on its territory. However, the author does not concur with this conventional vision of the role of the state and believes that seeing the state as a superior entity undermines the autonomy of society members. Hence, the author proposes his own concept of state authority, which he views as a reflection and testimony of the autonomous status of the individuals who compose its population. This particular standpoint, perhaps, opens room for academic debate.

Lata also puts forth an opinion that applying the Western pattern of state formation as a panacea to the existing problems of the region has to be reconsidered. Such suggestion encourages further study and reminds other academics to critically evaluate the Western models in regards to their applicability in the African region.

Above all, given the subject of state building is a burning issue in the region, policy makers, academics and other parties concerned are pressed to work on its realization in their respective areas. The reviewer believes that Lata's work will serve as an alarm for all parties involved in the state-building process in the Horn of Africa, who should give priority to interests of the people residing on the territory of the future state and strive, in the first place, for best of the region.

Methodologically, the work lacks variety of primary data sources, entirely depending on secondary sources. With regards to modernization, the author portrays and describes Christian Abyssinia, some northern Sudanese and Somali family clans who hold themselves out as different from the rest of the uncivilized local population and deem themselves as worthy counterparts to Europeans. The reviewer believes that, though such description has substance, in some respects it seems quite exaggerated, as, for example, the described family clans do not position themselves as competitors to the Western lifestyle.

The reviewer also feels that, in certain respects, the author follows a reductionist approach. Paying sufficient attention to dominant groups, such as Christian Abyssinia and northern Sudan, the book overlooks the role of other ethnic groups that participated in the process of state formation in the region. The reviewer further assumes that the author is overly preoccupied with the idiosyncrasy of the region, sometimes disregarding the real state of affairs. The Horn of Africa is described as peculiar in many respects, which, as is believed by the reviewer, is not consistent with the facts.

Furthermore, the author mis-conceptualizes the peace-keeping doctrine, seeing peace-making operations as a long-term strategy and the only way of realizing state-building in the Horn of Africa. However, the very genesis of peacekeeping operations contradicts the author's understanding of the purpose of peace-making, as PCOs emerged as an ad hoc response to the international crises after the formation of the United Nations. The reviewer argues that the mission of any peacekeeping operation in the world in general and in the Horn of Africa in particular solely consists in preventing further violence. 


\title{
Рецензия на монографию: Линко Лата Миротворчество как государственное строительство: современные вызовы для Африканского Рога. США, Эвинг Тауншип: The Red Sea Press. 2012. 160 с.
}

\author{
Б.Д. Гардашью \\ Университет Бахр-Дар \\ Бахр-Дар, Эфиопия
}

\begin{abstract}
Аннотация. В рецензии на книгу Линко Лата «Миротворчество как государственное строительство: современные вызовы для Африканского Рога» рассматривается теория и практика государственного строительства на примере ряда африканских стран. Центральным посылом этой работы является предположение о том, что государственное строительство требует переосмысления ряда факторов и атрибутов, традиционно ассоциируемых с государством. Книга состоит из девяти глав, каждая из которых анализируется рецензентом. Основное внимание в рассматриваемой монографии уделяется проблемам государственного строительства, государственной легитимности, а также роли и специфике миротворческих операций на Африканском Роге.
\end{abstract}

Ключевые слова: миротворчество, государственное строительство, Африканский Рог, демократия, политическая стабильность

\section{Информация об авторе:}

Бевукету Дирес Гардашью - преподаватель и исследователь департамента политологии и международных исследований университета Бахр-Дар (Эфиопия) (e-mail: bewuket23@gmail.com).

\section{Information about the author:}

Bewuketu Dires Gardachew - Lecturer and Researcher of the Department of Political Science and International Studies, Bahir Dar University (Ethiopia) (e-mail: bewuket23@gmail.com).

\section{Для цитирования:}

Gardachew B.D. Book review: Leenco Lata Peacekeeping as State-Building: Current Challenges for the Horn of Africa. Ewing Township, USA: The Red Sea Press. 2012. 160 p. // Вестник Российского университета дружбы народов. Серия: Государственное и муниципальное управление. 2019. Т. 6. № 4. С. 366-370. DOI: 10.22363/2312-8313-2019-6-4$366-370$

\section{For citation:}

Gardachew B.D. Book review: Leenco Lata Peacekeeping as State-Building: Current Challenges for the Horn of Africa. Ewing Township, USA: The Red Sea Press. 2012. 160 p. RUDN Journal of Public Administration. 2019; 6 (4): 366-370. DOI: 10.22363/2312-83132019-6-4-366-370 